\title{
Challenges in impact evaluation
}

Anrudh K. Jain

Population Council

Follow this and additional works at: https://knowledgecommons.popcouncil.org/departments_sbsr-rh

Part of the Community-Based Research Commons, Demography, Population, and Ecology Commons, Family, Life Course, and Society Commons, International Public Health Commons, and the Quantitative, Qualitative, Comparative, and Historical Methodologies Commons How does access to this work benefit you? Let us know!

\section{Recommended Citation}

Jain, Anrudh K. 2013. "Challenges in impact evaluation," presentation at the Consultation on Social and Behavioral Change Interventions for Enhancing Child Survival in South Asia, New Delhi, India.

This Presentation is brought to you for free and open access by the Population Council. 


\section{Challenges in Impact Evaluation}

\section{Anrudh K Jain Ph.D. Distinguished Scholar}




\section{Anticipated BCC Process}

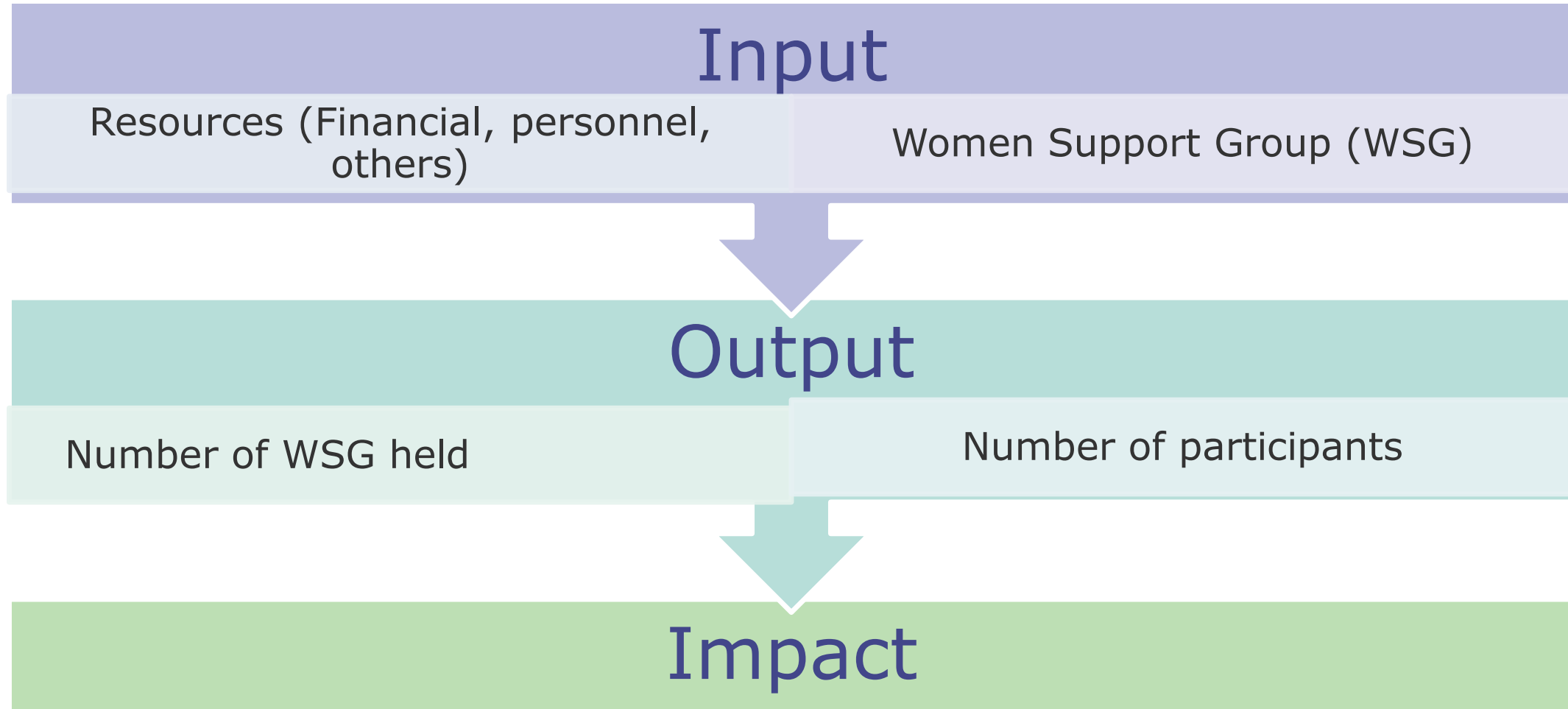

Messages received \& internalized

3+ ANC visits increased 


\section{Issues}

- Was the intervention implemented?

- WSG

- Any other

- What was its coverage?

- Did the behavior (e.g. 3+ ANC) change?

- Can change be attributed to WSG?

- Can change be sustained?

- Is WSG cost-effective?

- Will WSG reduce neo-natal mortality? 


\section{Type of designs}

- Post-facto evaluations

- Pre- and post-observations

- Experimental and control areas with pre- and post- observations

- Geographic variations 


\section{Illustrations from PAIMAN evaluation conducted by the Population Council}




\section{Post-facto evaluation}

$\%$ with 3+ANC

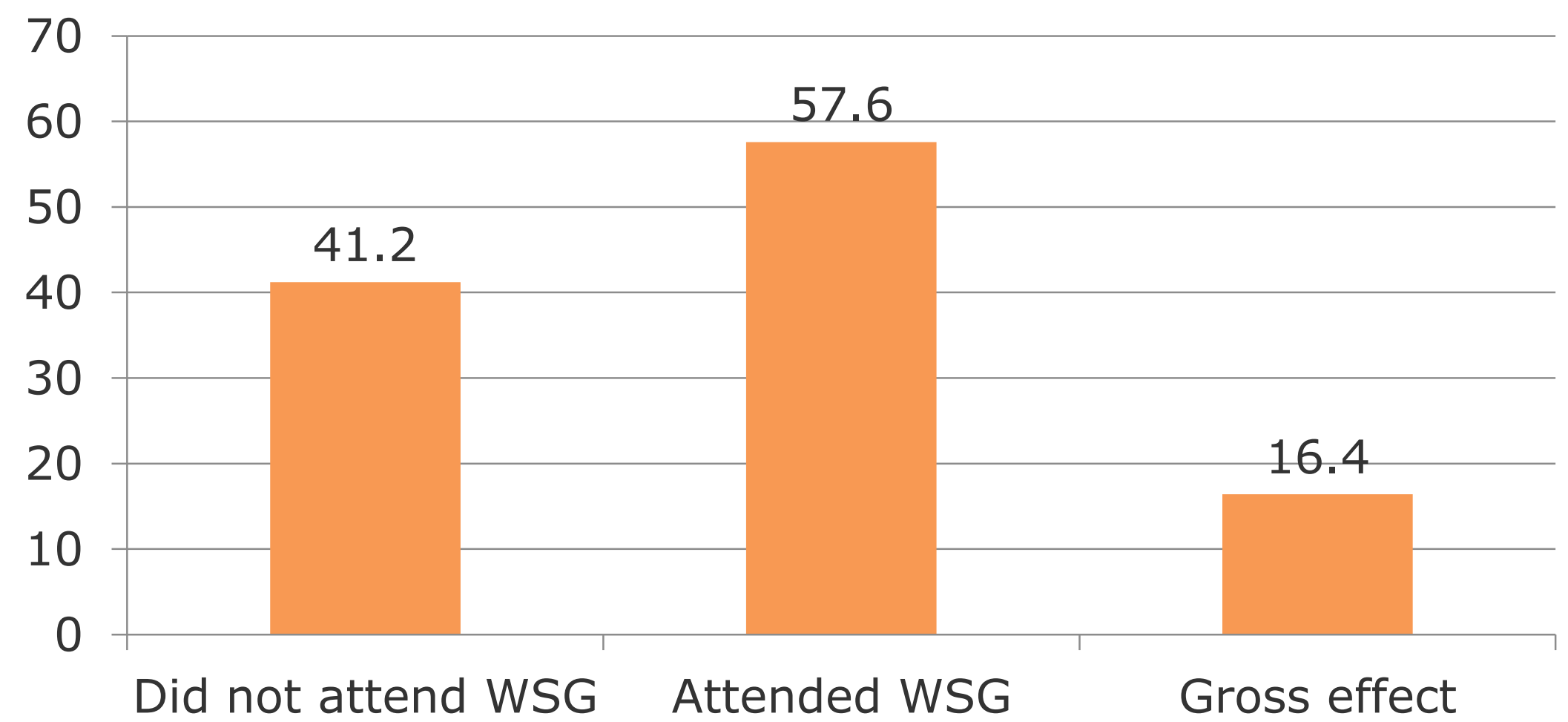




\section{Pre- and post- design}

3+ ANC

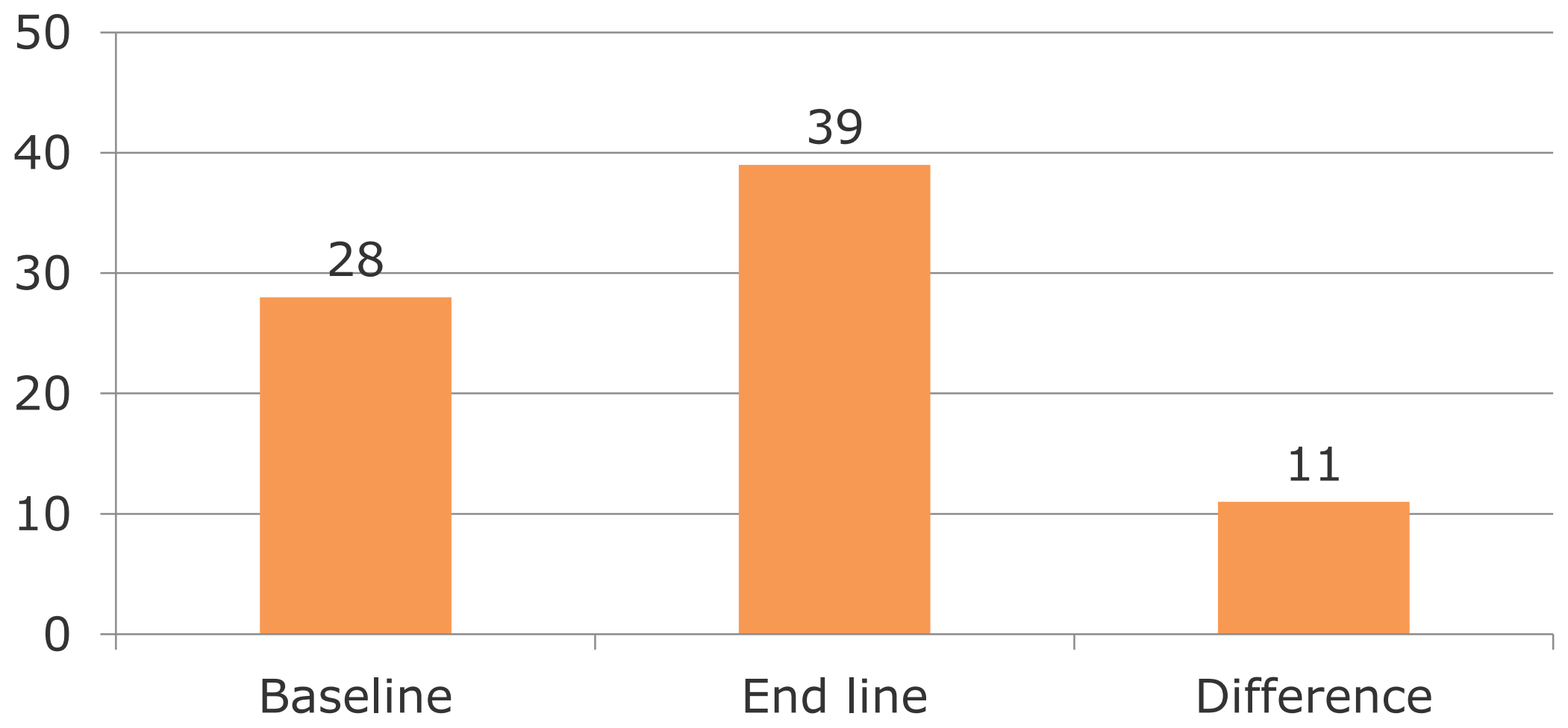




\section{Percent women with 3+ ANC visits in rural areas}

\section{Non-CHW area}

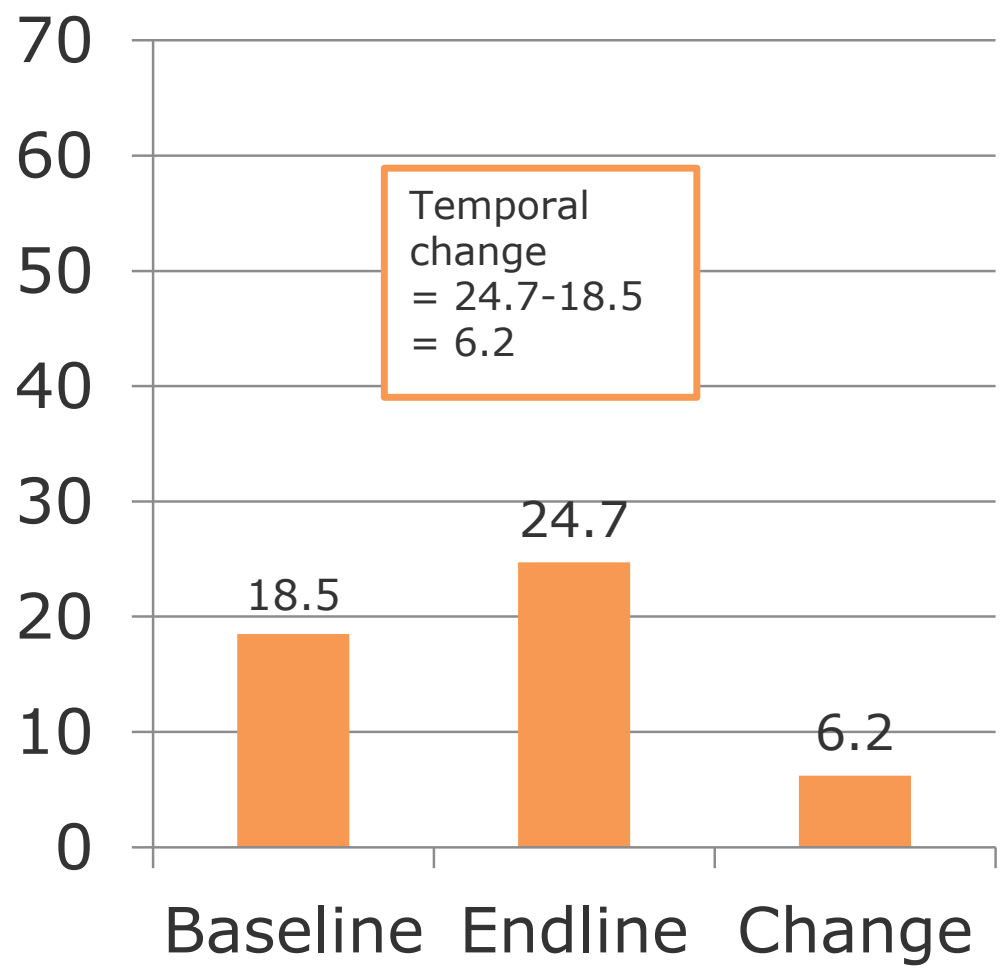

CHW area

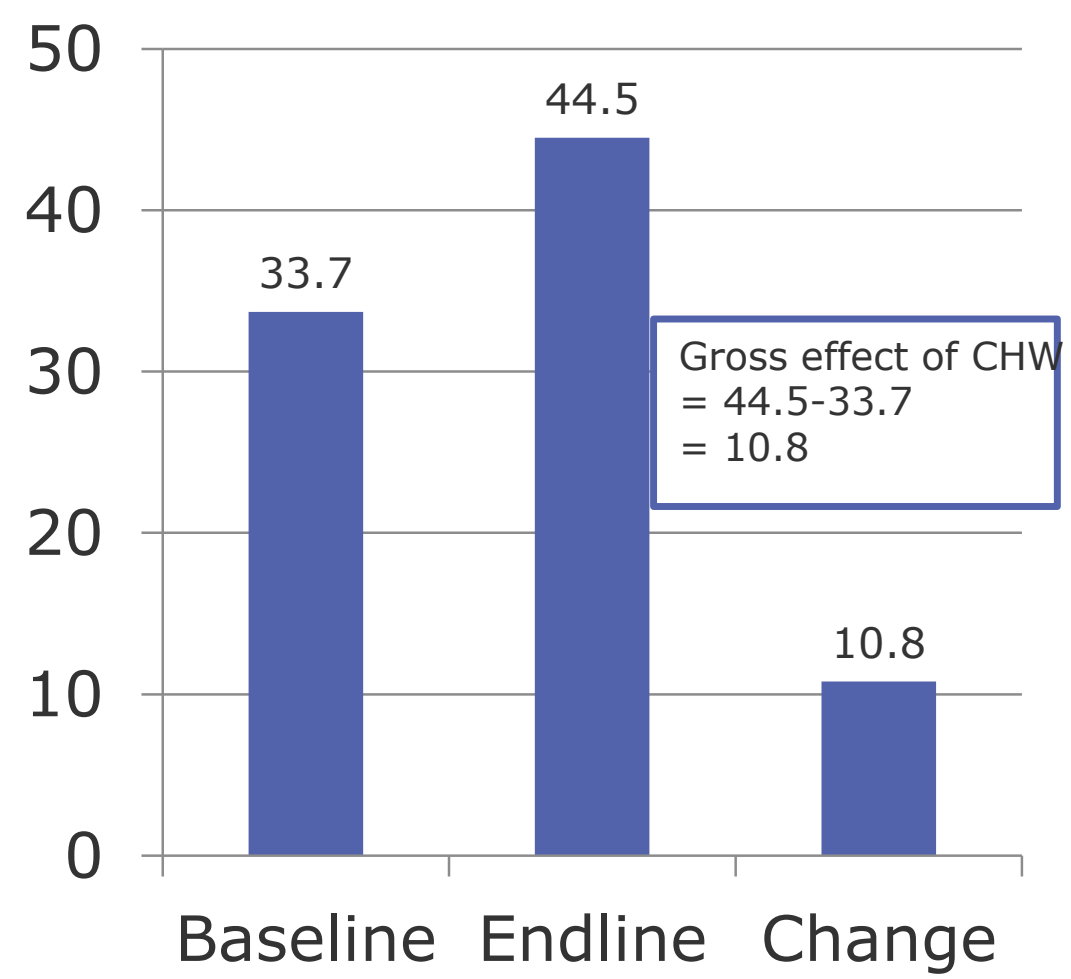




\section{Pre- and post-design}

Baseline $\square$ Temporal change $\square$ Change due to CHW

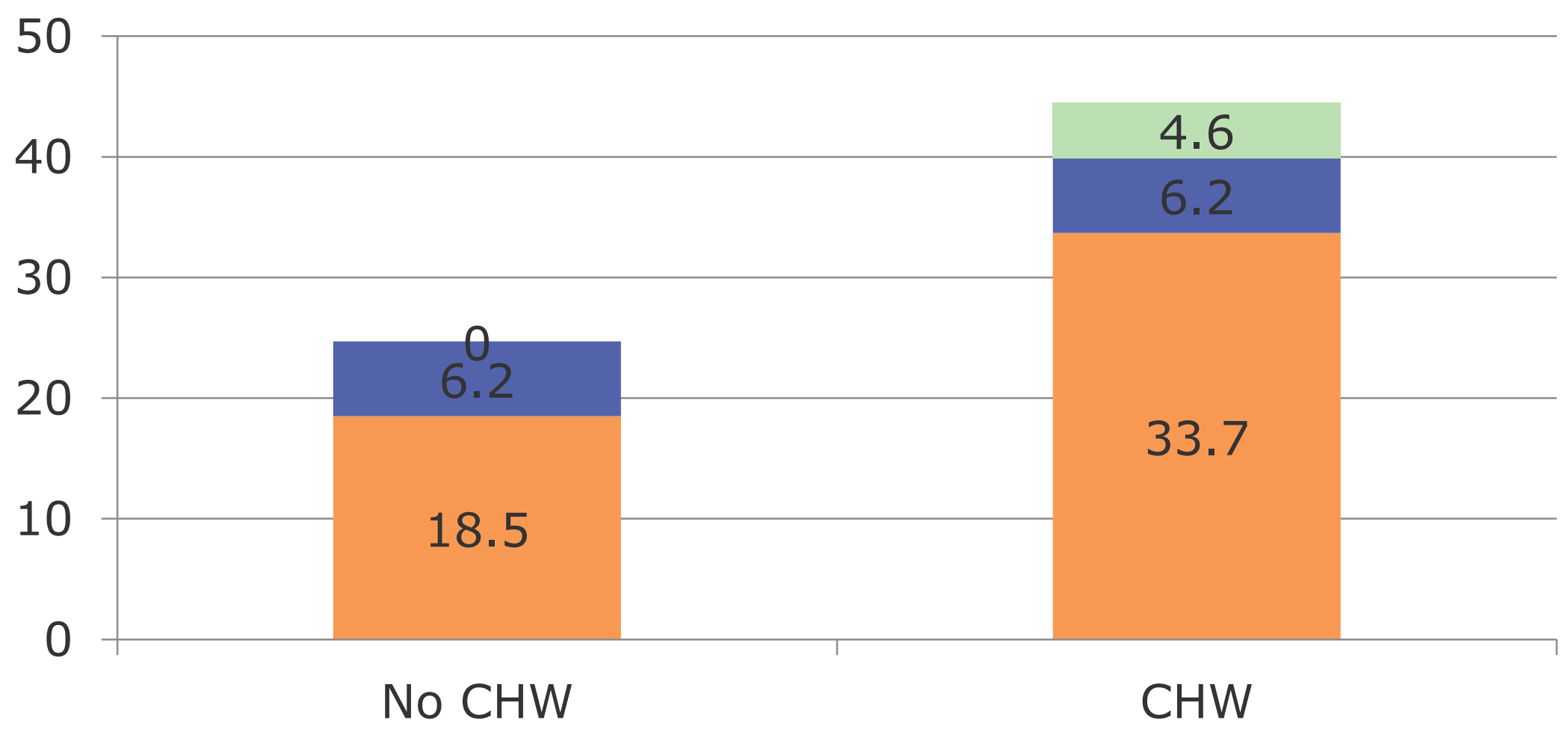




\section{Increase due to WSG in areas covered by CBW}

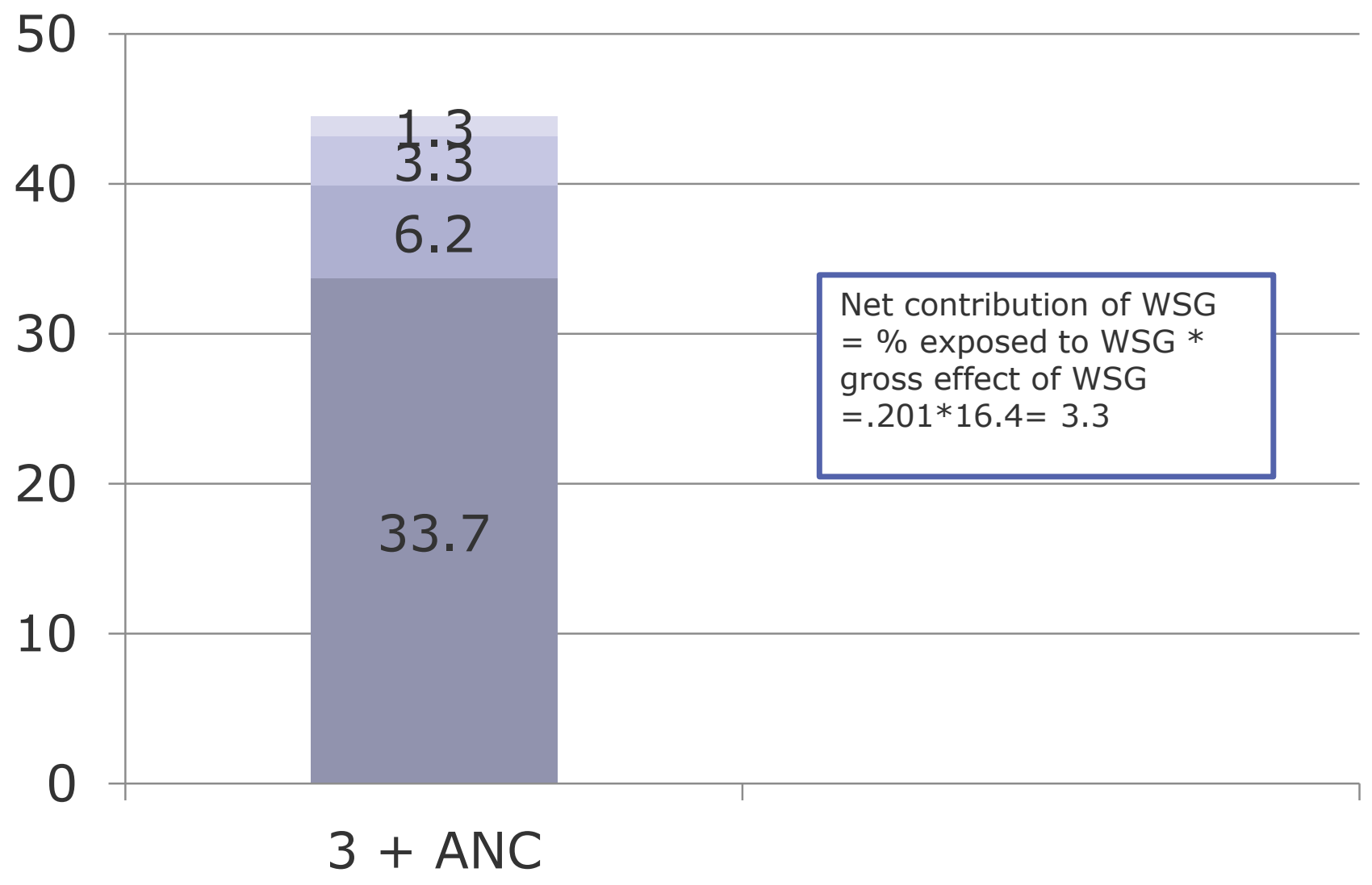

Other

WSG

- Temporal

Baseline 


\section{Effect of exposure to at least one intervention}

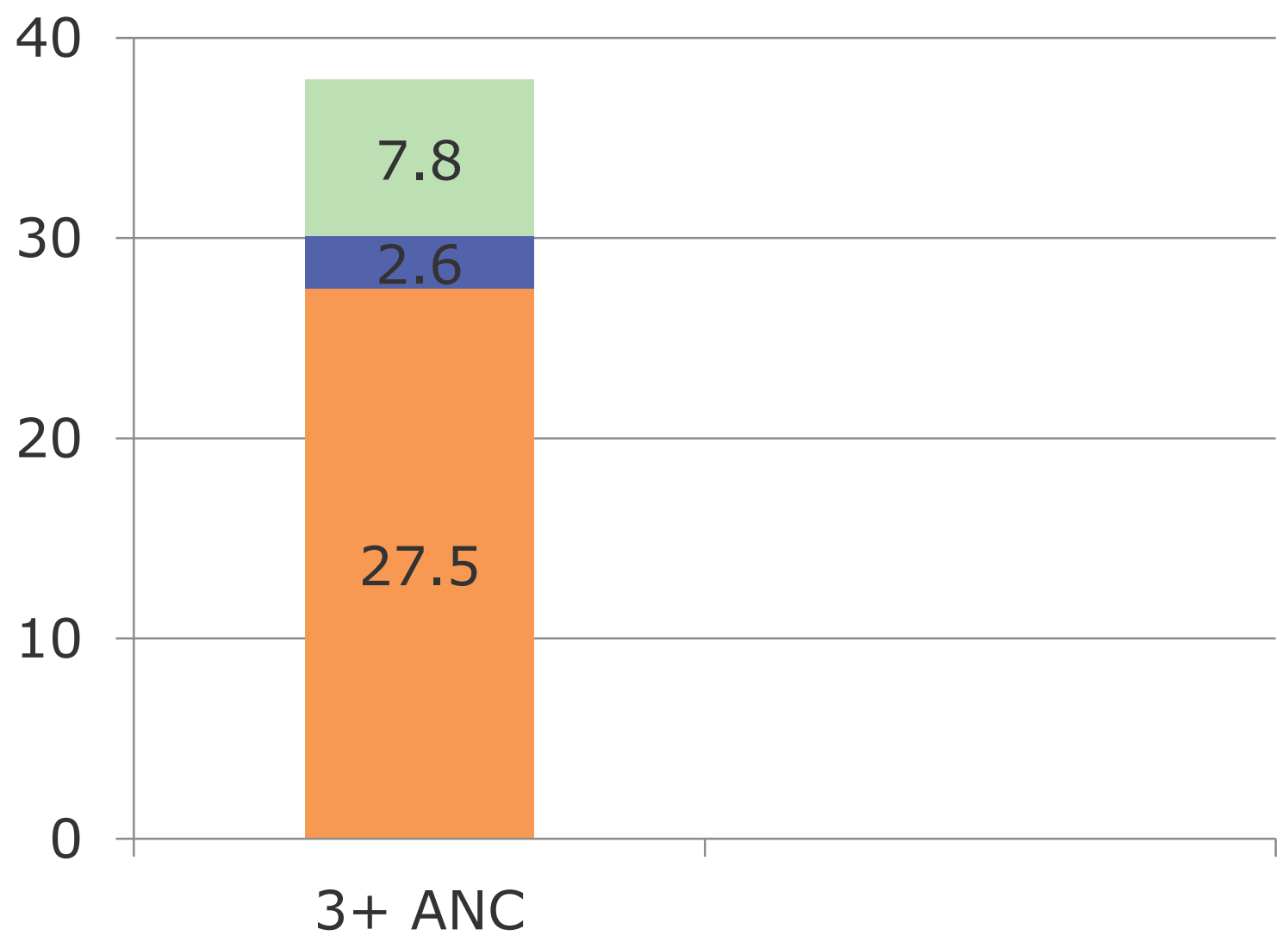

$1+$ intervention

- Temporal

Baseline 


\section{Remaining challenges}

- Selectivity

- Communities with and without CBW are not similar

- Women who attended and not attended WSG are not similar

- Overlap between effects of different interventions

- Attribution of effect to each intervention 


\section{Experimental and control with pre- and post-observations}

- Number of arms depends upon the number of questions to be addressed

-Whom to contact-Husband, wife, or both?

- How to contact-individually, in a group, media? 


\section{Slide with photo}

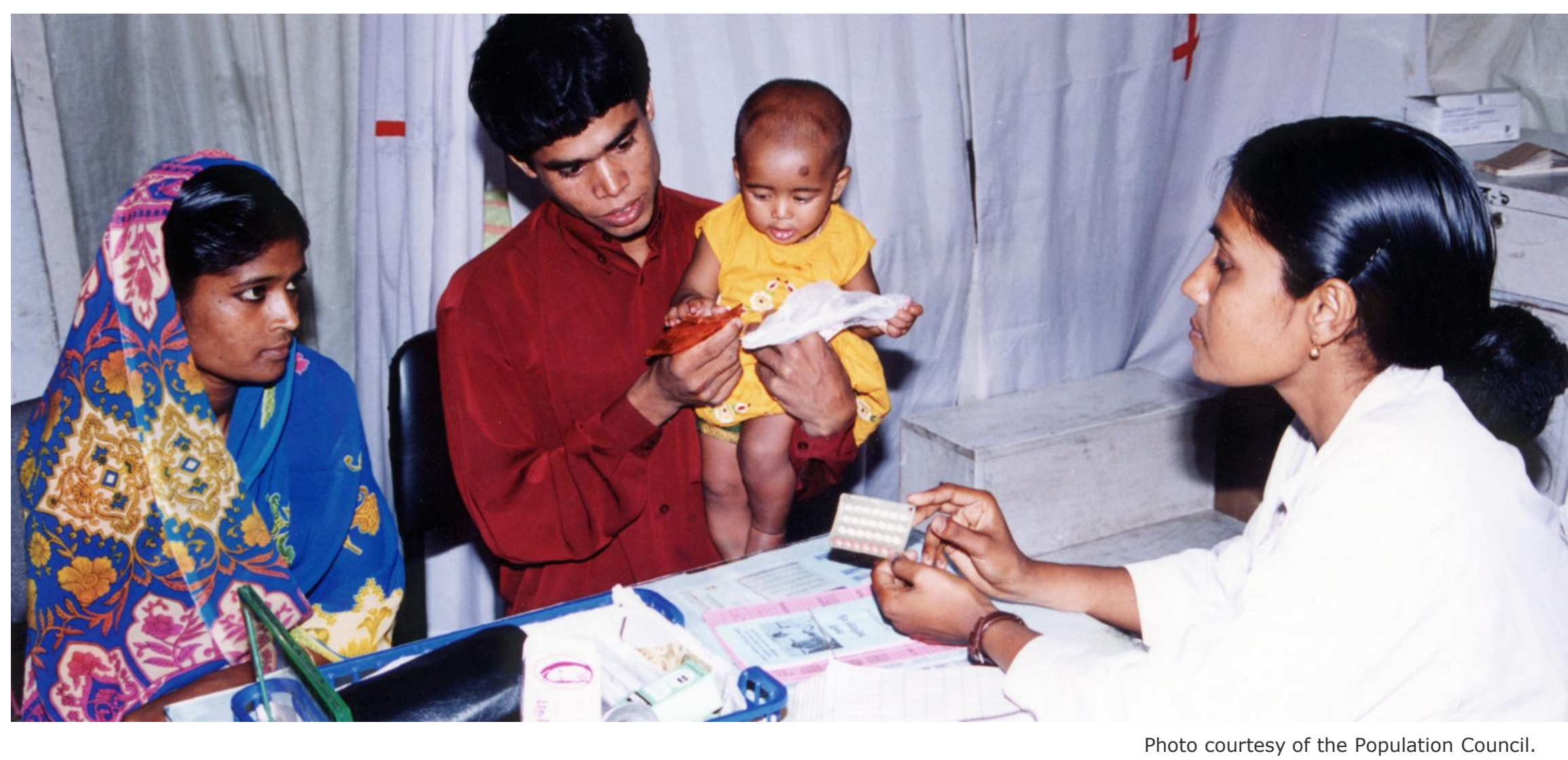

Will contacting husbands in addition to wives add to changed behavior? 


\section{Illustrative designs}

- Taichung experiment in social change conducted in early 1960s had 3 by 3 design that showed that contacting husbands in addition to wives did not increase acceptance of IUDs 


\section{Links between interventions and outcome indicators}

\begin{tabular}{|c|c|c|c|c|}
\hline $\begin{array}{l}\text { Intervent } \\
\text { ons }\end{array}$ & Behavior & Mechanis & $\begin{array}{l}\text { Outcome } \\
\text { indicator }\end{array}$ & Issue \\
\hline $\begin{array}{l}\text { JSY, P4P, } \\
\text { Vouchers, } \\
\text { IPC }\end{array}$ & $\begin{array}{l}\text { Institutional } \\
\text { delivery; } \\
\text { SBA }\end{array}$ & $?$ & MMR & $\begin{array}{l}\text { Does } \\
\text { intervention } \\
\text { affect } \\
\text { quality \& } \\
\text { coverage? }\end{array}$ \\
\hline $\begin{array}{l}\text { IPC, WSG, } \\
\text { Mid- and } \\
\text { Mass media }\end{array}$ & $\begin{array}{l}\text { ANC; Clean } \\
\text { delivery; } \\
\text { Early care; } \\
\text { Early and } \\
\text { exclusive } \\
\text { BF; } \\
\text { Kangaroo }\end{array}$ & $?$ & NMR & $\begin{array}{l}\text { Are } \\
\text { intervention } \\
\text { s competing } \\
\text { or } \\
\text { complimenti } \\
\text { ng }\end{array}$ \\
\hline
\end{tabular}




\section{Concluding remarks}

- No substitute for thinking of impact evaluation before programming

- Intervention must be strong enough to have an effect

- Direct effects on behavior are easier to measure than indirect effects on outcome indicators

- Effects are context specific 